\title{
PROPRIEDADES MOLECULARES DE UM ISOLADO BRASILEIRO DO Southern bean mosaic virus*
}

\author{
ANDREIA E. MOREIRA** \& JOSÉ O. GASPAR
}

\author{
Departamento de Zoologia e Botânica, IBILCE/UNESP, 15054-000 São José do Rio Preto, SP, Brasil, \\ e-mail: gaspar@bot.ibilce.unesp.br
}

(Aceito para publicação em 01/03/2002)

Autor para correspondência: José Osmar Gaspar

MOREIRA, A.E. \& GASPAR, J.O. Propriedades moleculares de um isolado brasileiro do Southern bean mosaic virus. Fitopatologia Brasileira 27:292-297. 2002.

\section{RESUMO}

Um isolado do Southern bean mosaic virus (SBMV), gênero Sobemovirus, encontrado em feijoeiro (Phaseolus vulgaris) no Estado de São Paulo, foi purificado e algumas de suas propriedades moleculares determinadas. As partículas virais apresentam diâmetro de $28-30 \mathrm{~nm}$ e proteína capsidial com massa molecular estimada em $30 \mathrm{kDa}$. Das partículas virais foi extraído RNA de vários tamanhos $(4,2 \mathrm{~Kb}, 3,1 \mathrm{~Kb}, 2,65 \mathrm{~Kb}, 2,15 \mathrm{~Kb}, 1,64$ $\mathrm{Kb}, 1,36 \mathrm{~Kb}$ e 1,0 Kb) sendo aquele de 4,2 Kb o RNA genômico e o de 1,0 Kb supostamente um subgenômico que codifica para a proteína capsidial. Ácidos ribonucleicos de mesmo tamanho foram também detectados in vivo, indicando estar associados à replicação viral. Na análise do RNA de fita dupla (dsRNA), somente duas espécies foram detectadas $(4,2 \mathrm{Kpb}$ e 1,0 Kpb) correspondendo às formas replicativas do RNA genômico e do subgenômico para proteína capsidial. Os resultados indicam que somente estes dois RNA são replicados por meio de formas replicativas (RFs), enquanto os demais devem ser formados talvez por iniciação interna da fita negativa do RNA genômico. O SBMV-B ${ }^{\mathrm{SP}}$ apresentou propriedades moleculares análogas àquelas do SBMV descrito na América do Norte.

Palavras-chave adicionais: replicação viral, dsRNA, Sobemovirus, proteína capsidial.

\section{ABSTRACT \\ Molecular properties of a Brazilian isolate of Southern bean mosaic virus}

An isolateof the Southern bean mosaic virus (SBMV), genus Sobemovirus, found in the State of São Paulo, Brazil, was purified and some of its molecular properties determined. The virus particles are $28-30 \mathrm{~nm}$ in diameter and the coat protein has a molecular mass of $30 \mathrm{kDa}$. A heterogeneous population of RNAs $(4.2 \mathrm{~Kb}, 3.1 \mathrm{~Kb}, 2.65 \mathrm{~Kb}, 2.15 \mathrm{~Kb}, 1.64 \mathrm{~Kb}, 1.36 \mathrm{~Kb}$ and $1.0 \mathrm{~Kb}$ ) was extracted from virus particles, where those of $4.2 \mathrm{~Kb}$ and 1.0 $\mathrm{Kb}$ are, respectively, the genomic and the putative subgenomic RNA for coat protein. RNAs of the same size were also extracted from infected common bean (Phaseolus vulgaris) leaves, indicating that they must have some function in the virus replication cycle. Only two species of double-stranded RNAs (dsRNA) were extracted from infected tissues $(4.2 \mathrm{Kbp}$ and $1.0 \mathrm{Kbp})$, corresponding to the replicative forms of the genomic RNA and the subgenomic RNA for coat protein. These results indicate that only these two RNAs replicate by means of replicative forms (RF) while the others are probably synthesized by an internal initiation of the negative strand of the genomic RNA. The SBMV-B ${ }^{\mathrm{SP}}$ showed molecular properties analogous to the SBMV described in North America.

\section{INTRODUÇ̃̃̃O}

O feijoeiro (Phaseolus vulgaris L.) constitui uma das culturas mais importantes, assumindo, no Brasil, um grande valor social pois é a base de alimentação da população como fonte de proteína vegetal de baixo custo. A produção mundial de feijão é da ordem de 18,9 milhões de toneladas, sendo o Brasil o segundo maior produtor (2,2 milhões de toneladas), somente superado pela Índia (4,9 milhões de toneladas) (Cultura, 2000). A produtividade da cultura é grandemente afetada pela ocorrência de doenças que diminuem sensivel-

\footnotetext{
*Parte da Dissertação de Mestrado da autora apresentada à Universidade Estadual Paulista (2001). Apoio financeiro: FAPESP e CAPES. **Bolsista da CAPES
}

mente a produção e, conseqüentemente, reduzem sua oferta, provocando um aumento nos preços de mercado (Cultura, 2000). Estas doenças têm exercido um papel relevante na baixa produtividade do feijoeiro no Brasil e outros países latino-americanos, sendo as mais numerosas as ocasionadas por fungos seguindo-se as de etiologia viral, algumas tendo adquirido expressiva importância econômica (Gamez, 1977).

No Brasil, foram descritas mais de dez viroses em feijoeiro (Costa et al., 1972; Bianchini et al., 1997), citandose entre elas as causadas pelo Southern bean mosaic virus (SBMV), gênero Sobemovirus (van Regenmortel et al., 2000). Este vírus tem uma restrita gama de hospedeiras, confinada quase que exclusivamente a espécies da família das leguminosas, sendo algumas de interesse econômico como o feijoeiro comum e a soja. 
O SBMV possui partículas isométricas $(28-30 \mathrm{~nm})$ contendo RNA genômico de 4-4,5 Kb com polaridade positiva e proteína capsidial com massa molecular de 29-30 kDa (Shepherd, 1971; Sehgal, 1981). Uma pequena proteína (VPg) é covalentemente ligada à extremidade 5 ' do RNA, enquanto a extremidade 3' é destituída de cauda Poli A (Ghosh et al., 1979). O genoma do SBMV codifica para uma possível proteína de movimento, uma poliproteína (presumivelmente contendo a VPg, uma serino protease e a RNA polimerase dependente de RNA) e a proteína capsidial (Othman \& Hull, 1995; Lee \& Anderson, 1998) sendo, esta última, traduzida a partir de um RNA subgenômico (Rutgers et al., 1980; Ghosh et al., 1981). As partículas virais contêm, além do RNA genômico, uma população heterogênea de RNAs sendo que proteínas são sintetizadas in vitro a partir destes (Rutgers et al., 1980).

No Brasil, o SBMV foi detectado pela primeira vez em feijoeiros na região do Distrito Federal $\left(\mathrm{SBMV}^{\mathrm{DF}}\right)$, ocasionando sintomas que variam, dependendo da cultivar, de mosaico fraco a severo, deformação da vagem e distorção foliar (Cupertino et al., 1982). Posteriormente, mas ainda na década de 80, o vírus foi também encontrado no Estado de São Paulo (A. S. Costa. Dados não publicados) e será doravante referido como SBMV ${ }^{\mathrm{SP}}$. Os estudos com o SBMV no Brasil são relacionados com a identificação (gama de hospedeiras e sorologia), transmissão, ocorrência e ultraestrutura de tecidos infetados, não havendo, entretanto, nenhuma informação sobre aspectos moleculares. Assim, com o propósito de caracterizar o SBMV-B ${ }^{\mathrm{SP}}$ do ponto de vista molecular, vários estudos estão sendo realizados e, no presente trabalho, são relatados os resultados referentes à purificação viral e determinação de algumas propriedades da proteína capsidial e dos RNA associados ao vírus.

\section{MATERIAL E MÉTODOS}

\section{Vírus/planta}

O SBMV-B ${ }^{\mathrm{SP}}$ foi doado pelo Dr. Álvaro Santos Costa (Instituto Agronômico de Campinas), no final dos anos 80, e mantido em folhas dessecadas a $-80{ }^{\circ} \mathrm{C}$. Para o presente trabalho, o SBMV-B ${ }^{\mathrm{SP}}$ foi inoculado mecanicamente em feijoeiro 'Rosinha' e mantido em casa de vegetação com temperatura ao redor de $28{ }^{\circ} \mathrm{C}$.

Purificação viral e extração de RNA e proteína capsidial O SBMV-B ${ }^{\mathrm{SP}}$ foi purificado como descrito por Hull (1977), com pequenas modificações. O método envolveu trituração das folhas de feijoeiro em tampão fosfato de sódio $0,1 \mathrm{M} \mathrm{pH} \mathrm{7,2,} \mathrm{clarificação} \mathrm{com} \mathrm{clorofórmio}(0,5 \mathrm{ml} / \mathrm{g}$ de folha), precipitação do vírus com polietilenoglicol (PEG 8000) a $10 \%$ e cloreto de sódio a $1 \%$, um ciclo de alta e baixa rotações $(16000 \mathrm{~g} / 10 \mathrm{~min}$ e $100000 \mathrm{~g} / 90 \mathrm{~min})$ e gradiente de sacarose (10-50\%) em tampão fosfato de sódio 0,01 M pH 7,2. A banda contendo vírus foi diluída, centrifugada a $100000 \mathrm{~g}$ por 90 min e o "pellet" ressuspendido em tampão fosfato de sódio $0,01 \mathrm{M} \mathrm{pH} \mathrm{7,2.}$
O RNA das partículas virais foi extraído por tratamento com SDS 2,5\%, $\mathrm{NaCl} 0,1 \mathrm{M}$, aquecimento a $55^{\circ} \mathrm{C}$ por $3 \mathrm{~min}$ e extração com fenol saturado com tampão citrato de sódio $0,1 \mathrm{M} \mathrm{pH} 4,3$. O RNA foi precipitado da fase aquosa com acetato de sódio $0,3 \mathrm{M}$ e 3 vol de etanol, enquanto a proteína capsidial foi precipitada da fase fenólica pela adição de 5 vol de acetona $\left(-20^{\circ} \mathrm{C} / 20 \mathrm{~h}\right)$. O RNA foi ressuspendido em águaDEPC e a proteína em tampão Tris. $\mathrm{HCl} 0,125 \mathrm{M}$ pH 6,8 contendo SDS 4\%, glicerol 20\%, 2-mercaptoetanol 10\% e azul de bromofenol 0,001 M.

\section{Extração de proteínas totais}

Cem mg de folhas de feijoeiro (sadio e infetado) foram homogeneizadas em tampão Tris. $\mathrm{HCl} 0,05 \mathrm{M} \mathrm{pH} \mathrm{7,5}$ contendo sacarose $0,4 \mathrm{M}, \mathrm{MgCl}_{2} 0,005 \mathrm{M}, \mathrm{KCl}$ 0,01 M e glicerol 20\%, centrifugadas a $16.000 \mathrm{~g}$ por $10 \mathrm{~min}$ e as proteínas precipitadas e ressuspendidas como descrito para a proteína capsidial.

\section{Eletroforese e "Western blot"}

As proteínas foram separadas em gel desnaturante de poliacrilamida contendo SDS por $90 \mathrm{~min}$ a $100 \mathrm{~V}$ em aparelho Mini Protean II (Bio Rad). A transferência para membrana de nitrocelulose foi feita em um eletrotransferidor (Mini Trans-Blot; Bio Rad) a 100 V por 60 min utilizando-se tampão Tris-Glicina (Tris 0,025 M, Glicina 0,192 M contendo metanol 20\%). A imunolocalização da proteína capsidial foi feita com anti-SBMV-B ${ }^{\mathrm{SP}}$ obtido em galinha na diluição de 1:2.000. Como anti-soro secundário foi utilizado anti-IgG de galinha (obtido em coelho) conjugado com fosfatase alcalina (Sigma) diluído 1:50.000 e BCIP/NBT como substrato.

\section{Extração de RNA total}

O RNA total de folhas de plantas sadias e infetadas foi extraído usando TRIzol, como recomendado pelo fabricante (Gibco/BRL).

\section{Produção de sonda}

Uma sonda não radioativa foi preparada pela incorporação ao acaso do esteróide digoxigenina (DIG-dUTP; Boehringer Mannheim) usando como molde RNA isolado do SBMV-B ${ }^{\mathrm{SP}}$ purificado e Transcriptase Reversa Superscript II Rnase $\mathrm{H}^{-}(\mathrm{Gibco} / \mathrm{BRL})$.

\section{"Northern blot" e detecção}

O RNA viral e o RNA total extraído de plantas sadias e infetadas foram separados em gel desnaturante de agarose/ formaldeído, fotografados e a seguir transferidos, sob vácuo, para membrana de náilon. A hibridização com a sonda não radioativa foi feita a $50{ }^{\circ} \mathrm{C}$ por $20 \mathrm{~h}$, em solução contendo

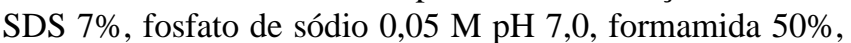
SSC 5x (SSC 1x = citrato de sódio 0,03 M pH 7,0; $\mathrm{NaCl}$ 0,3 $\mathrm{M}), \mathrm{N}$-lauroylsarcosina $0,1 \%$ e reagente bloqueador $2 \%$ (Boehringer Mannhein). As membranas foram lavadas com SSC $2 \mathrm{x}$ contendo SDS $0,1 \%$ ( 2 x $5 \mathrm{~min}$, temperatura ambiente) e SSC $1 \times$ contendo SDS $0,1 \%\left(2 \times 15 \mathrm{~min}, 68^{\circ} \mathrm{C}\right)$. A detecção foi feita com anti-digoxigenina conjugado com 
fosfatase alcalina, substrato quimioluminescente (CDP-Star; Amersham-Pharmacia) e exposição em filme de raio X (XOMAT, Kodak).

\section{RESULTADOS E DISCUSSÃO}

As partículas purificadas do SBMV-B ${ }^{\mathrm{SP}}$ (Figura 1) apresentaram diâmetro de 28-30 nm, similar aqueles determinados para outros isolados do SBMV (Weintraub \& Ragetli, 1970; Sehgal, 1981). A proteína capsidial migrou, em gel desnaturante de SDS-PAGE, como polipeptídio único, com massa molecular estimada em $30 \mathrm{kDa}$ (Figura 2.1). Este valor está próximo daqueles obtidos para outros isolados do SBMV, que variam de 28,5 a $30 \mathrm{kDa}$ (Tremaine, 1966; Ghabrial et al., 1967; Hull 1977). Ressalta-se que dados da sequiência de aminoácidos da proteína capsidial do SBMV indicam a presença de 270 resíduos de aminoácidos com massa molecular de 29,3 kDa (Tremaine, 1966). A proteína capsidial do SBMV-B ${ }^{\mathrm{SP}}$ foi também evidenciada in vivo por "Western blot" e anti-soro específico (Figura 2.2), não tendo sido detectados produtos de degradação o que confirma sua acentuada estabilidade in vitro (Sehgal, 1981).

Os resultados da eletroforese, em gel desnaturante de agarose, do RNA extraído das partículas do SBMV-B ${ }^{\mathrm{SP}}$ e do RNA total extraído de feijoeiros infetados e sadios (Figura 3.1) revelaram para o RNA extraído dos vírions uma banda maior com tamanho molecular de $4,2 \mathrm{~Kb}$, além de várias outras de menor tamanho, das quais uma encontra-se melhor definida, com aproximadamente 1,0 Kb. Não há diferença no padrão de bandas nas amostras de RNA total extraído de planta infetada pelo SBMV-B ${ }^{S P}$ e de planta sadia. Um gel similar a este foi transferido por "Northern-blot" e hibridizado com sonda não radioativa específica ao genoma do SBMV

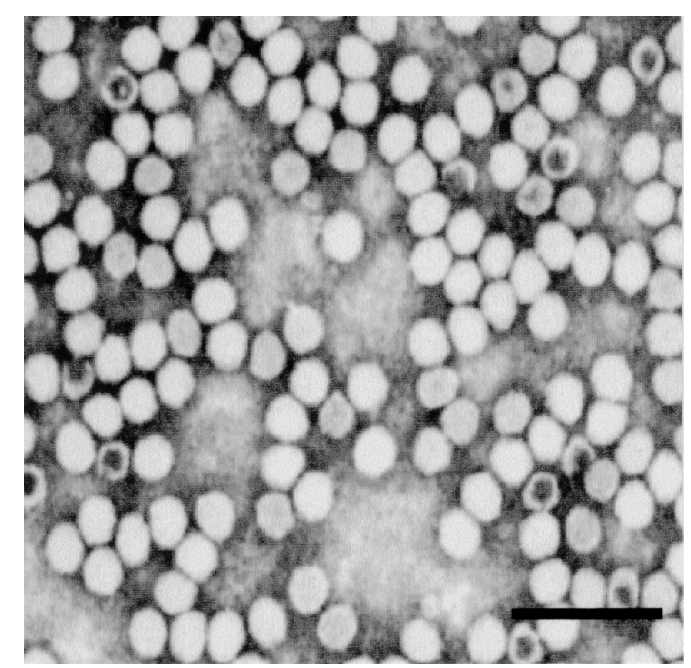

FIG. 1 - Preparação purificada do Southern bean mosaic virus (SBMV-B ${ }^{\mathrm{SP}}$ ) contrastada negativamente com acetato de uranila $2 \%$ e observada ao microscópio eletrônico de transmissão. A barra representa $100 \mathrm{~nm}$.
(Figura 3.2). Tanto na amostra de RNA extraído dos vírions como na de RNA total, extraído de planta infetada, houve reação com a banda de $4,2 \mathrm{~Kb}$, bem como com vários outros RNA de menor tamanho $(3,1 \mathrm{~Kb}, 2,65 \mathrm{~Kb}, 2,15 \mathrm{~Kb}, 1,64 \mathrm{~Kb}$, $1,36 \mathrm{~Kb}$ e 1,0 Kb). Nenhuma reação foi observada com o RNA total extraído de planta sadia. A banda de 4,2 Kb corresponde ao RNA genômico, enquanto a banda de 1,0 Kb é referida, por alguns autores, como sendo o RNA subgenômico que codifica para a proteína capsidial do vírus (Rutgers et al., 1980; Ghosh et al., 1981).

O "Northern-blot" do RNA total de folhas infetadas, após hibridização com a sonda para o SBMV, mostrou um padrão de bandas similar àquele do RNA extraído dos vírions, demonstrando que, além do RNA genômico, os outros RNA de diferentes tamanhos são também relacionados com o genoma viral.

Por muito tempo considerou-se que o SBMV era um típico exemplo de vírus contendo uma cadeia de RNA como único componente genético (Diener, 1965; Shepherd, 1971). Os estudos com o isolado americano do SBMV (Rutgers et al., 1980; Ghosh et al., 1981; Weber \& Sehgal, 1982) e as observações com o isolado brasileiro, contradizem este conceito evidenciando que as estratégias de replicação do vírus provavelmente são muito mais complexas. O presente trabalho com o SBMV-B ${ }^{\mathrm{SP}}$, além de confirmar a heterogeneidade dos RNA virais, demonstrou pela primeira vez que estes, além

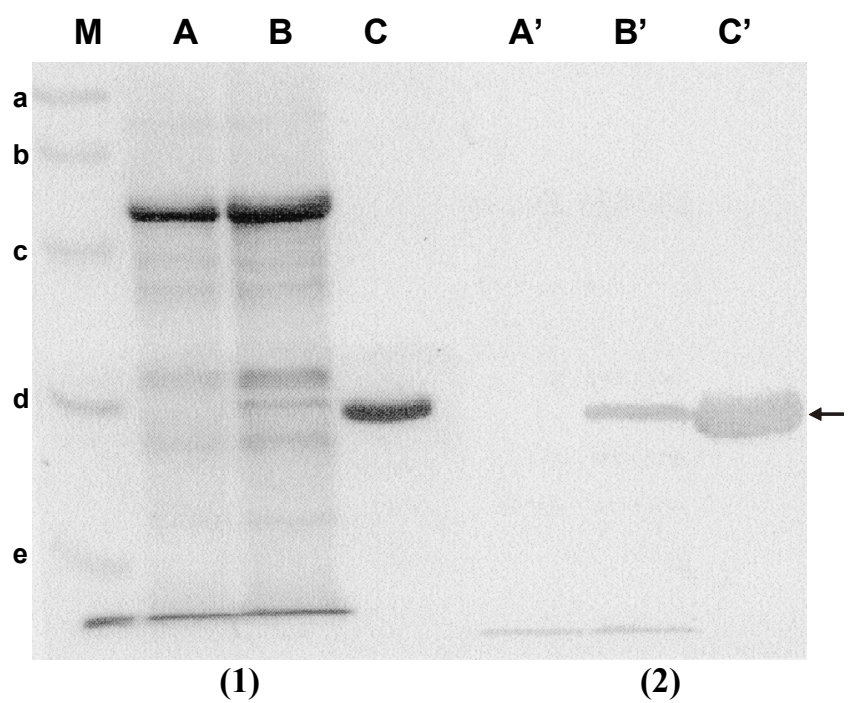

FIG. 2 - (1) Perfil eletroforético de extrato de planta sadia de feijoeiro (Phaseolus vulgaris) (A), planta infetada (B) e Southern bean mosaic virus (SBMV-B ${ }^{\text {SP }}$ ) purificado (C). (2) "Western blot" e reação imunológica de um gel similar ao (1) para a detecção da proteína capsidial do SBMV-B ${ }^{\mathrm{SP}}$ (seta). M, marcadores de massa molecular (Low Range; Bio Rad): a, fosforilase B (97,4 kDa); b, albumina bovina $(66,2 \mathrm{kDa})$; c, ovoalbumina $(45,0$ kDa); d, anidrase carbônica (31,0 kDa); e, inibidor de tripsina de soja $(21,5 \mathrm{kDa})$. 
dos vírions, também estão presentes em quantidades detectáveis na planta hospedeira, o que sugere que devam exercer alguma função relacionada com a infecção viral.

Weber \& Sehgal (1982) consideraram todos os RNA de tamanho menor do que o RNA genômico como sendo subgenômicos (sgRNA) e sugeriram que todos estariam envolvidos na produção das proteínas codificadas pelo genoma do SBMV, atuando como "cistrons". Segundo esses autores, os sgRNAs poderiam ter surgido pelo processamento do genoma viral, como ocorre com vários vírus que infetam animais (Rothenberg et al., 1978) ou por uma transcrição preferencial de segmentos selecionados da fita negativa do RNA genômico (que é produzida durante a replicação), sendo esta última hipótese já considerada para outros vírus de plantas (Atabekov \& Morozov, 1979). No entanto, Rutgers et al. (1980) e Ghosh et al. $(1979,1981)$ consideraram apenas o RNA de 1,0 Kb como subgenômico, sendo responsável pela codificação da proteína capsidial do SBMV. Foi verificado que o sgRNA de $1,0 \mathrm{~Kb}$ possui as 91 bases de sua extremidade 3' idênticas à seqüência da extremidade correspondente do RNA genômico de comprimento total e, assim como o RNA genômico, este sgRNA possui uma VPg (proteína ligada covalentemente ao RNA viral) ligada à sua extremidade 5' (Ghosh et al., 1979, 1981). Devido a estas observações inferiuse que a informação genética para a proteína capsidial estaria presente no RNA genômico como um "cistron" silencioso que se expressa através de um RNA subgenômico encapsidado em quantidades diminutas (Rutgers et al., 1980; Ghosh et

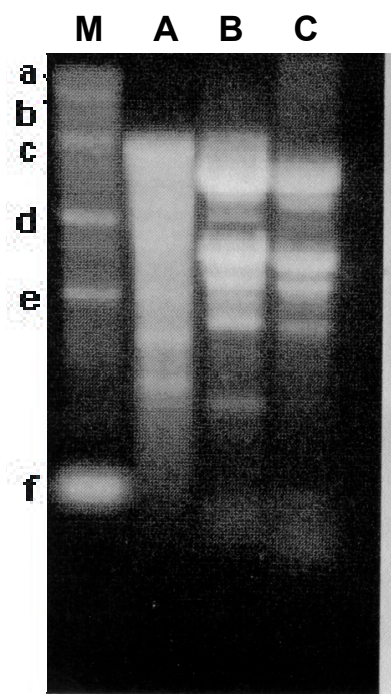

(1)

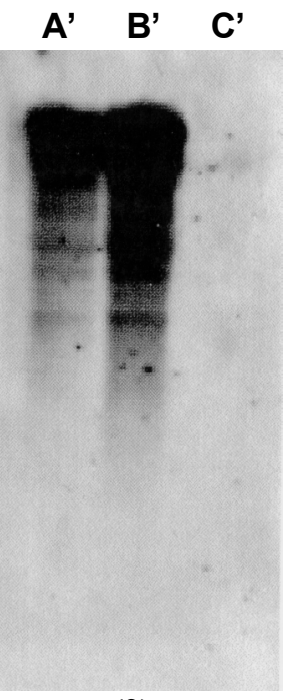

(2)
FIG. 3 - (1) Análise do RNA viral (A) e do RNA total extraído de planta infetada pelo Southern bean mosaic virus (SBMV-B ${ }^{\mathrm{SP}}$ ) (B) e de planta sadia (C) em gel desnaturante de agarose $1 \% . \mathrm{M}$, marcador RNA Ladder, Gibco-BRL: a, 9,49 Kb; b, 7,46 Kb; c, 4,40 Kb; d, 2,37 Kb; e, 1,35 Kb; f, 0,24 Kb. (2) "Northern blot" de um gel similar ao (1) hibridizado com sonda específica para o genoma do SBMV-B ${ }^{\mathrm{SP}}$. al., 1981). "Cistrons" silenciosos para proteínas estruturais são observados em outros gêneros de vírus de plantas como os dos gêneros Tobamovirus e Tymovirus, e também em vírus de animais como os gêneros Togavirus e Retrovirus (Matthews, 1991). Em todos estes casos, um mRNA subgenômico para proteínas estruturais, sintetizado in vivo, funciona muito eficientemente como mensageiro in vitro. Essa estratégia de replicação aumenta muito a eficiência de produção da proteína estrutural em questão que, no caso do SBMV, é a proteína capsidial necessária em grandes quantidades para a montagem de partículas virais. Isto explicaria a função do sgRNA de $1,0 \mathrm{~Kb}$, mas não a função dos outros RNAs observados.

$\mathrm{Na}$ análise do RNA de fita dupla (dsRNA) do SBMV$\mathrm{B}^{\mathrm{SP}}$ (Figura 4) duas espécies foram detectadas em planta de feijoeiro infetada pelo SBMV-B ${ }^{\mathrm{SP}}$ e ambas hibridizaram com a sonda, mostrando estarem relacionadas com o genoma do vírus. A identificação de que os RNAs são de fita dupla vem do fato destes terem sido tratados (e não digeridos) com DNAse I e Nuclease S1 ao final do processo de extração (Dados não mostrados). A banda de 4,2 Kpb refere-se à forma replicativa do RNA genômico $(4,2 \mathrm{~Kb})$ pois apresenta o dobro do tamanho deste, enquanto que a banda de $1,0 \mathrm{Kpb}$ referese à forma replicativa do RNA subgenômico que codifica para a proteína capsidial $(1,0 \mathrm{~Kb})$.

Os RNAs de fita dupla presentes em plantas infetadas

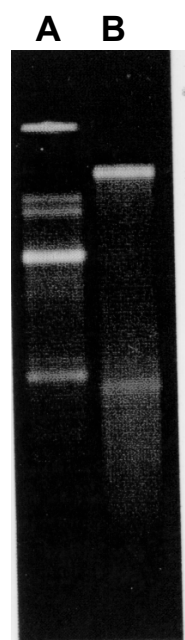

(1)
B'

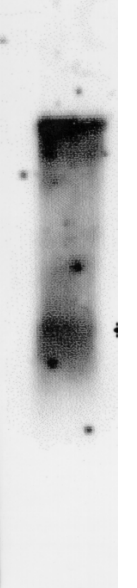

(2)
FIG. 4 - (1) Perfil eletroforético dos dsRNA extraídos e purificados em celulose CF-11. A, marcadores constituídos de mistura de dsRNA de Tobacco mosaic virus (TMV) (6,4 Kpb) e Cucumber mosaic virus (CMV) (3,9 Kpb; 3,3 Kpb; 2,5 Kpb; e 1,0 Kpb). B, dsRNA extraídos de folhas de feijoeiro (Phaseolus vulgaris) infetado pelo Southern bean mosaic virus (SBMV-B $\left.{ }^{\mathrm{SP}}\right)$. (2) "Northern blot" de um gel similar ao (1) hibridizado com sonda específica para o genoma do SBMV-B ${ }^{\mathrm{SP}}$. A seta indica o dsRNA genômico e o asterisco o provável dsRNA subgenômico. 
por vírus, cujo genoma consiste de RNA de fita simples (ssRNA), constituem uma forma replicativa (RF) originada durante a replicação viral. O fato de os dsRNAs do SBMV serem apenas dois, em contraposição com os vários RNAs de fita simples observados, mostra que somente estes estão se replicando através da formação de um intermediário replicativo de fita negativa. Pode-se aventar duas hipóteses para explicar este fato: a de que os outros RNAs visualizados são apenas produtos de degradação do RNA genômico de comprimento total, não se replicando dentro da planta hospedeira, ou que a replicação destes RNA heterogêneos ocorra de uma forma diferente daquela do RNA genômico como, por exemplo, pela iniciação interna da fita negativa do RNA genômico como já citado por Weber \& Sehgal (1982) e também observado para os vírus do gênero Bromovirus (Hull \& Maule, 1985).

A constatação do presente trabalho de que os RNAs heterogêneos apareceram como bandas bem definidas e de tamanho constante nas várias extrações realizadas, evidenciam que estes desempenham uma função definida dentro da planta hospedeira, não se tratando apenas de produtos de degradação do RNA genômico. Esta função pode ser apenas estrutural, ou seja, como as interações específicas RNA-capa proteica são necessárias para a montagem das partículas virais (Sehgal, 1981), os RNAs heterogêneos poderiam desempenhar uma função na morfogênese viral. Por outro lado, eles poderiam estar atuando como "cistrons" para as proteínas virais como uma estratégia para otimizar a produção destas. Uma evidência que fortalece tal hipótese são os experimentos de Rutgers et al. (1980), nos quais verificou-se que todos estes RNAs funcionam como mensageiros in vitro. A proteína P4 (12 kDa) do SBMV-B, por exemplo, teve sua tradução induzida por todos os RNAs de diferentes tamanhos observados. O que fica evidente é que estes RNAs apresentam um mecanismo de replicação diferente daquele do RNA genômico, sem formação de formas replicativas ou dsRNA.

Os resultados obtidos no presente trabalho demonstram que o SBMV-B ${ }^{\mathrm{SP}}$ apresenta propriedades moleculares semelhantes àquelas do SBMV descrito na América do Norte, constituindo evidências adicionais de que se tratam de vírus semelhantes. Estudos de seqüenciamento das regiões 5' e 3' terminais do RNA genômico do SBMV-B ${ }^{\mathrm{SP}}$ permitirão uma definição do grau de similaridade entre esses isolados.

\section{AGRADECIMENTOS}

Ao Dr. Hugo Kuniyuki (Centro de Fitossanidade, Instituto Agronômico de Campinas) pelas sugestões e revisão do manuscrito.

\section{REFERÊNCIAS BIBLIOGRÁFICAS}

ATABEKOV, J.G. \& MOROZOV, T. Translation of plant virus messengers. Advances in Virus Research 25:1-91. 1979.

BIANCHINI, A., MARINGONI, A.C. \& CARNEIRO, S.M.T.P.G.
Doenças de feijoeiro. In: Kimati, H., Amorin, L., Bergamin Filho, A., Camargo, L.E.A. \& Rezende, J.A.M. (Eds.) Manual de Fitopatologia, $3^{\text {nd }}$ ed., Agronômica Ceres, 1997. pp. 376399.

COSTA, A.S., KITAJIMA, E.W., MIYASAKA, S. \& ALMEIDA, L.D. Moléstias de feijoeiros causadas por vírus. Anais, I Simpósio Brasileiro do Feijão/ Viçosa, 1972. pp. 342-384.

CULTURA-FEIJÃO; Bahia, 2000. Disponível em <http:// www.seagri.ba.gov.br/feijão1.htm> Acesso em: 24 janeiro 2001.

CUPERTINO, F.P., LIN, M.T., KITAJIMA, E.W. \& COSTA, C.L. Occurrence of southern bean mosaic virus in central Brazil. Plant Disease 66:742-743. 1982.

DIENER, T.O. Isolation of infectious ribonucleic acid from southern bean mosaic virus. Virology 27:425-429. 1965.

GAMEZ, R. Las enfermedades virales como factores limitantes en la produccion de frijol (Phaseolus vulgaris L.) en America Latina. Fitopatologia 12:24-26. 1977.

GHABRIAL, S.A., SHEPHERD, R.J. \& GROGAN, R.G. Chemical properties of three strains of southern bean mosaic virus. Virology 33:15-25. 1967.

GHOSH, A., DASGUPTA, R., SALERNO-RIFE, T., RUTGERS, T. \& KAESBERG, P. Southern bean mosaic virus has a 5'linked protein but lacks 3' terminal poly (A). Nucleic Acids Research 7:2137-2146. 1979.

GHOSH, A., RUTGERS, T., MANG, K.Q. \& KAESBERG, P. Characterization of coat protein mRNA of southern bean mosaic virus and its relationship to the genomic RNA. Journal of Virology 39: 87-92. 1981.

HULL, R. The banding behavior of the viruses of southern bean mosaic virus group in gradients of cesium sulphate. Virology 79: 50-57. 1977

HULL, R. \& MAULE, A.J. Virus multiplication In: Francki, R.I.B.(Ed.) The Plant Viruses, Polyhedral Viruses with Tripartite Genomes. Plenum Press, vol. 1, 1985. pp. 245-267.

LEE, L. \& ANDERSON, J. Nucleotide sequence of a resistance breaking mutant of southern bean mosaic virus. Archives of Virology 143:2189-2201. 1998.

MATTHEWS, R.E.F. Plant Virology. $3^{\text {th }}$ ed. New York. Academic Press, Inc. 1991.

OTHMAN, Y. \& HULL, R. Nucleotide sequence of the bean strain of southern bean mosaic virus. Virology 206: 287-297. 1995.

ROTHENBERG, E., DONOHUE, D.J. \& BALTIMORE, D. Analysis of a 5'-leader sequence on murine leukemia virus 21 S RNA: heteroduplex mapping with long reverse transcriptase products. Cell 13:435-451. 1978.

RUTGERS, T., SALERNO-RIFE, T. \& KAESBERG, P. Messenger RNA for the coat protein of southern bean mosaic virus. Virology 104:506-509. 1980.

SEHGAL, O.P. Southern Bean Mosaic Virus Group. In: Kurstak, P. (Ed.) Handbook of Plant Virus Infections and Comparative Diagnosis. Elsevier/North Holland, 1981. pp. 91-121.

SHEPHERD, R.J. Southern bean mosaic virus. In: Descriptions of plant viruses. Commonwealth Mycological Institute/ Association of Applied Biologists, Kew, Surrey, England, $\mathrm{n}^{\circ}$ 57, 1971.

TREMAINE, J.H. The amino acid and nucleotide composition of the bean and cowpea strains of southern bean mosaic virus. Virology 30: 348-254. 1966.

VAN REGENMORTEL, M.H.V., FAUQUET, C.M., BISHOP, D.H.L., CARSTENS, E.B., ESTES, M.H., LEMON, S.M., 
Propriedades moleculares de um isolado brasileiro do Southern bean...

MANILOFF, J., MAYO, M.A., MCGEOCH, D.J., PRINGLE, C.R. \& WICKNER, R.B. Virus Taxonomy: seventh report of the International Committee on Taxonomy of Viruses. Academic Press. 2000.

WEBER, K.A. \& SEHGAL, O.P. Subgenomic RNAs in virions of southern bean mosaic virus. Phytopathology 72:909-913. 1982. WEINTRAUB, M. \& RAGETLI, H.W.J. Electron microscopy of the bean and cowpea strains of Southern Bean Mosaic Virus within leaf cells. Journal of Ultrastructural Research. 32:167189. 1970 . 